\title{
Tectono-History of the Silurian Sharawra Formation in Northwestern and Central Arabia
}

\author{
Abdulaziz A. Al-Laboun* \\ Geology Department - Faculty of Geology - King Saud University - Riyadh - Saudi Arabia
}

\section{A R T I C L E I N F O}

Article history:

Received 21 November 2010

Accepted 25 September 2011

Keywords:

Silurian shales;

Sharawra;

Caledonian time;

Tectonic movements;

Tawil Formation.

\section{A B S T R A C T}

The distribution of the Silurian shales of the Qusaiba Formation of Arabia was affected by pre-existing Late Ordovician paleo-highs and the Silurian sandstones of the Sharawra Formation were severely influenced by the syntectonic Acadian movements.

Detailed lithologic correlation and structural analyses of the Sharawra sections indicate that pronounced thinning of the formation eastward is due to tectonic influence rather than depositional. This thinning is attributed to Late-Silurian Early Devonian tectonic movements. These movements are believed to be synchronous with the Acadian uplift phase of the Caledonian time, which have rejuvenated pre-Silurian paleo-highs and causing severe truncation of thick deposits of the Sharawra Formation prior to the deposition of the Late SilurianEarly Devonian? Tawil Formation.

Two main structural elements that affected the Sharawra Formation in central Arabia are represented by the north-south trending and northerly plunging Hail Arch and to a much lesser the northwest-southeast trending and southerly plunging Qusayba high.

\section{Introduction}

The present work aims to study the Early Silurian Sharawra Formation in northwestern and central Arabia to understand its tectonic setting and depositional history (Figure 1).

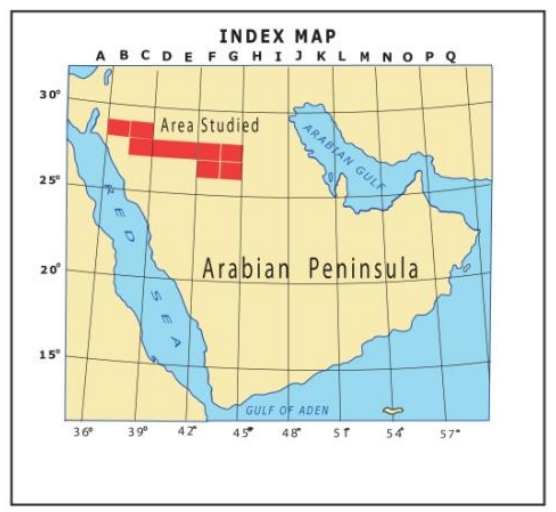

Fig. 1: Index map showing the location of the studied area in northwestern and central Arabian Peninsula.

The Tabuk and Widyan basins offer excellent outcrops to document the tectonic and depositional history of the Sharawra Formation (Figure 2).

\footnotetext{
* Corresponding author.

E-mail address: ibnlaboun@yahoo.com

Box 63280 Riyadh 11516
}

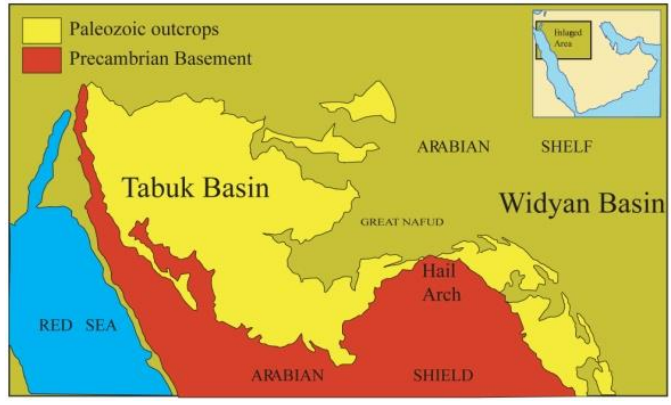

Fig. 2: Distribution of the outcrops of the Lower Paleozoic rocks in northwestern and central Arabian Peninsula.

This paper is based on field investigation and literature review of published work.

The study area extends from Tabuk in the west to Qusayba in the east. The area covers Tabuk, Qalibah, Tayma, Baq'a and Buraydah quadrangles. This paper is based on the author's field work and geological data published by Janjou and others ${ }^{1}$ (Tabuk quadrangle), Janjou and others ${ }^{2}$ (Al Qalibah quadrangle), Vaslet and others $^{3}$ (Tayma quadrangle), Janjou and others ${ }^{4}$ (Jabal Misma quadrangle), Bartlett and others ${ }^{5}$ (Hail quadrangle), Vaslet and others ${ }^{6}$ (Baq'a quadrangle), Manivit and others $^{7}$ (Buraydah quadrangle), and Williams and others ${ }^{8}$ (Jabal Habashi quadrangle). 
Paleozoic rocks are exposed as a great curved belt parallel to the northern margin of the Arabian Shield. These rocks are best exposed in Tabuk and Widyan basins (Figure 2).

The Paleozoic succession is represented by CambroOrdovician Saq Formation; Ordovician Qasim Formation; Late Ordovician Zarqa/Sarah formations; Silurian Uqlah, Qusaiba, and Sharawra formations; Devonian Tawil, Jauf, and Jubah formations; Carboniferous-Permian? Shajara Formation, Late Permian Unayzah Formation, and Permian-Triassic Khuff Formation (Figure 3).

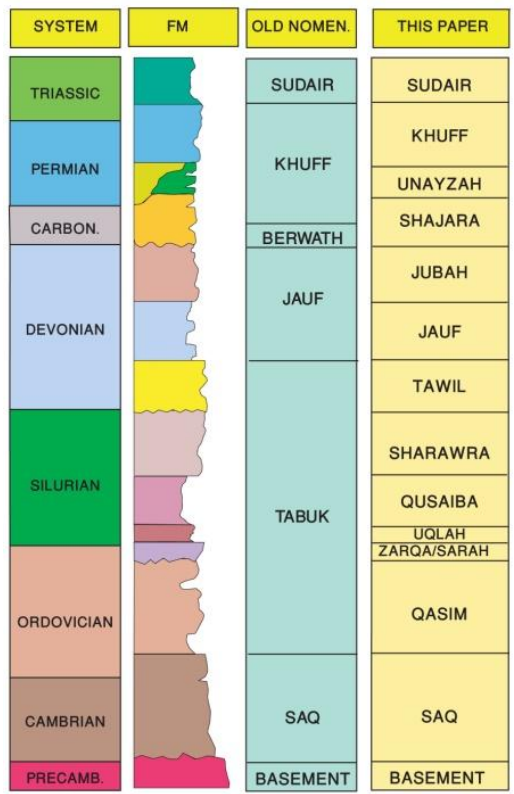

Fig. 3: Old terminology of the Ordovician-Silurian-Devonian succession of the Tabuk Formation (Powers and others, 1966) and Paleozoic lithostratigraphic units and nomenclature followed in this study.

Stratigraphic relationships of outcrop sections of the Sharawra Formation from Tabuk area to Qusayba area were studied to establish the tectonic influences on the Sharawra Formation.

The Silurian succession is represented by marine sandstones and shales of the Uqlah Formation, marine shales of the Qusaiba Formation, and deltaic micaceous siltstones and sandstones of the Sharawra Formation (Figures 3 and 4).

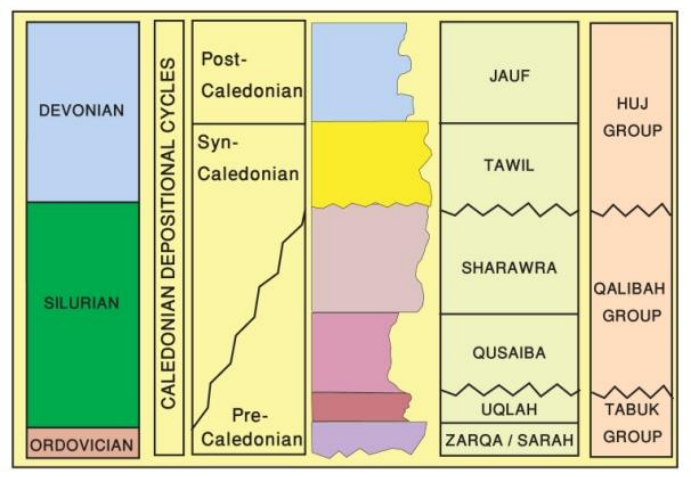

Fig. 4: Generalized subdivision of the Lower Paleozoic succession into mega depositional cycles as a result of the Late Silurian Acadian time -equivalent tectonic movements.

\section{Previous Work:}

The eastern part of the study area (Al-Qasim region) was mapped by Burchfiel and Hoover ${ }^{10}$ and Pocock and Koop ${ }^{11}$. The western part (Tabuk region) was mapped by Bramkamp and others ${ }^{12}$ (in Roach) (Aramco unpublished report, in Laboun ${ }^{23}$ ). These and other early field works of Aramco geologists were summarized and published by Thralls and Hasson ${ }^{13,14}$, Steineke and others ${ }^{15}$, Powers and others ${ }^{9}$, and Powers ${ }^{16}$. Series of geologic investigation maps were published by USGS and Aramco from 1956 to 1963. Paleontologic studies were published by Rickards and Koren ${ }^{17}$, El-Khayal ${ }^{18,19}$, ElKhayal and Romano ${ }^{20}$, and McClure $^{21}$. Regional geologic works were carried out by Laboun ${ }^{22-31}$, and Vaslet $^{32-35}$. Detailed geologic mapping was carried out by Bureau de Recherches Geologiques et Minieres (BRGM) geologists. Mahmoud and others ${ }^{36}$ mapped and discussed regional distribution of the Sharawra Formation in northern and central Arabia.

\section{Definition and Description of the Silurian Rock:}

Pocock and Kopp ${ }^{11}$, were the first to measure and describe Lower Silurian rocks in central Arabia. About 45 meters were measured in a composite of three sections in a steep cliff west of the village of Qusayba, Al-Qasim (Aramco, unpublished report, in Laboun ${ }^{23}$ ).

These rocks were named the "Qusaiba shale" and informally defined by Pocock and Kopp ${ }^{11}$ as the upper member of the Lower Ordovician-Lower Silurian "middle Uyun Formation" (obsolete) of the "Uyun Group" (obsolete). The middle member is the "ErRa'an" and the lower member is "Hanadir".

Silurian rocks were also reported from Tabuk area in the northwest of Arabia, by Bramkamp and others ${ }^{12}$. The field work in the Tabuk area was reported by Roach $^{37}$ (Aramco unpublished report, in Laboun ${ }^{29}$ ), Bramkamp and others ${ }^{12}$ (in Roach) replaced the term "middle Uyun Formation" (obsolete) of Pocock and $\mathrm{Kopp}^{11}$ in central Arabia by a new term for the Lower Ordovician- Silurian rocks, the "Tabuk Formation" (obsolete) (Figure 3) which included the three members "Sharaura", Er-Ra'an", and "Hanadir" with two intervening unnamed sandstone units.

The term "Tabuk formation" (obsolete) was first appeared in a summary paper of the stratigraphy of Saudi Arabia by Thralls and Hasson ${ }^{13,14}$ for Ordovician and Silurian rocks. Six Paleozoic formations were shown in a table and a cross section published by Thralls and Hasson ${ }^{13,14}$. Though the formations were not formally defined, a generalized lithology, thickness, and age were shown.

The measured and described section of the Tabuk Formation (obsolete) by Bramkamp and others ${ }^{12}$ (in Roach), in Tabuk area was accepted and formally published by Steineke and others ${ }^{15}$ as the type section for the Ordovician-Silurian rocks of the formally defined the Tabuk Formation (obsolete). Steineke and others ${ }^{15}$ discarded the terms "Sharaura", "Qusaiba", ErRa'an", and "Hanadir". 
Helal $^{38}$ amended the formally defined Tabuk Formation (obsolete) by confining it to the Ordovician rocks and introduced and formally defined the term "Sharawra Formation" for the Silurian rocks. Powers and others ${ }^{9}$ included the Devonian Tawil Sandstone as the upper member of the Tabuk Formation (obsolete) and divided the formation as measured and described by Bramkamp and others ${ }^{12}$ (in Roach and in Powers and others ${ }^{9}$ ), into seven lithologic units they retained only the basal unit, Han, "Sharaura adir member and discarded the other units", "Qusaiba", and Er-Ra'an" members.

\section{Sharawra Reinstated:}

The term "Sharaura" was introduced by Pocock and Kopp $^{11}$ for a member in the middle Uyun Formation (obsolete). This member and other members of the formation were discarded by Steineke and others ${ }^{15}$ when they formally defined the Tabuk Formation and by Powers and others 9 and Powers ${ }^{16}$ when they redefined this formation.

The term "Sharawra" as spelt and published by Helal ${ }^{38}$ was used and reinstated as a member of the Tabuk Formation by Laboun ${ }^{22,23}$. The other members of the Tabuk Formation (obsolete) Ra'an and Qusaiba were used and reinstated by Laboun ${ }^{22,23}$ as well. This practice was accepted and the terms Ra'an, Qusaiba, and Sharawra were used by geologists and appeared on the geologic maps.

\section{Tabuk Formation Discarded:}

Since the formal definition of the Tabuk Formation (obsolete) by Steineke and others ${ }^{15}$ the formation was used, amended, and redefined formally and informally by many geologists; Layne and Reese ${ }^{39}$, Bramkamp and others $^{40-41}$, Brown and others ${ }^{42}$, Helal ${ }^{38}$, Powers and others $^{9}$, McClure ${ }^{43}$, Clark-Lowes ${ }^{44}$, Laboun ${ }^{22,23}$, and Lozej $^{45}$. The Tabuk Formation (obsolete) was raised to a group rank "Tabuk Group" by El-Khayal and Romano ${ }^{20}$ and Janjou and others ${ }^{1}$.

The recognition of regional unconformities within the Tabuk Formation (obsolete) by McClure ${ }^{43}$, ClarkLowes $^{44}$, Laboun ${ }^{22,23}$, Vaslet ${ }^{32}$ and others resulted in revising the lithostratigraphic nomenclature of the Lower Paleozoic where the term "Tabuk Formation" (obsolete) was discarded and new formations were introduced as shown in Figure 3.

\section{New Formations Introduced:}

The BRGM geologists substituted the term "Tabuk Formation" by seven formations: the Qasim Formation (Ordovician) $^{6}$, Zarqa Formation (Ordovician) ${ }^{6}$, Sarah Formation (Ordovician- Silurian) ${ }^{8}$, Uqlah Formation (Silurian) $)^{1}$ Qusaiba Formation (Silurian) ${ }^{2}$, and Sharawra Formation (Silurian) ${ }^{2}$, and Tawil Formation (?Silurian-Devonian) ${ }^{2}$ (Figure 3). The term "Tayyarat Formation" was first appeared in the publication by Le Strat and others ${ }^{46}$ but it was originally proposed by Vaslet and others ${ }^{6}$ to include the Qusaiba and Sharawra members in the Baq'a quadrangle. Since the term "Tayyarat" was already used by Dunnington and others ${ }^{47}$ for a Cretaceous formation in south Iraq, the term "Tayyarat Formation" was discarded by Mahmoud and others ${ }^{36}$ and it was replaced by the term "Qalibah Formation".

\section{Tabuk and Qalibah Groups:}

The term Tabuk was reintroduced by Janjou and others ${ }^{2}$ as a group "Tabuk Group" to include "all the deposits assigned to the glacial episode that affected the continent of Gondwana during the Late Ordovician". It means that this group includes the Zarqa, Sarah, and Uqlah Formations.

Janjou and others ${ }^{2}$ raised the Qalibah Formation of Mahmoud and others ${ }^{36}$ to a group status "Qalibah Group" and raised the Qusaiba and Sharawra to formation ranks (Figure 3).

\section{Geologic Setting:}

\section{Stratigraphy:}

Lower Paleozoic rocks are well exposed in the studied area from Tabuk to Buraydah (Figure 2). The Cambrian to Early Ordovician? Sandstones and siltstones of the Saq Formation (Risha, Sajir, and Hilwan members) rests non-conformably on the Proterozoic rocks of the Arabian Shield. The Ordovician shales and sandstones of the Qasim Formation (Hanadir shale, Kahfah sandstone, Ra'an shale, and Quwarah sandstone members) rests conformably on the Saq Formation. The Late Ordovician to Early Silurian? glacial and peri-glacial sediments are represented by the Zarqa, Sarah (Hawban shale member), and Uqlah formations. These glacial deposits fill in paleo-valleys unconformably incised in the members of Saq and Qasim formations. The Early Silurian shales and sandstones are represented by the Qusaiba and Sharawra formations, respectively. The Sharawra Formation is unconformably overlain by the Late Silurian? to Early Devonian sandstones of the Tawil Formation (Figure 3).

The Early and Middle Devonian shales, limestones and sandstones are represented by the Jauf Formation (Sha'iba, Qasr, Subbat, Hammamiyat, and Murayr members) and Jubah Formation. These rocks are exposed in a window in the Jawf area in the north (Figure 3).

The Carboniferous Shajara Formation includes the Berwath Formation of Hermer and Owens (1968) which was defined from Well ST-8 that drilled at Wadi Aba Arawath south of Ara'r town, northern Arabia.

The Shajara Formation is best exposed a its type locality at the Wadi Ash-Shajara in the Qusayba depression and in a narrow strip from Niqrat Ablaq and Ash-Shiqqah, north of Buraydah, to Wadi Ar-Rayn in the south. The Shajara Formation rest unconformably on all older units from the Carboniferous to the Precambrian. This Sub-Shajara unconformity represents the influence of the Hercynian tectonic movements.

The Permian rocks are represented by the Unayzah Formation (Shiqqah and Safra members) is best exposed at the base of the Khuff carbonates escarpment. The Late Permian is represented by the Khuff (Huqayl, Duhaysan, and Midhnab members, - Triassic: Khartam 
member) Formation (Figure 3). The PermoCarboniferous rocks (Shajara, Unayzah, and Khuff Formations) are exposed in the Widyan Basin, east of the Hail arch.

\section{Acadian Tectonic Movements:}

Following the Late Ordovician Taconic movements and glaciation periods, thick Early Silurian shales of the Qusaiba Formation were deposited. During Late Silurian the region went through another series of gentle movements contemporaneous with the Acadian tectonic phase of the Caledonian orogeny (Laboun, in press). The early phase of this movement may have started after the deposition of the Sharawra Formation. This movement reached its maximum phase prior to the deposition of the Tawil Formation. The influence of the Acadian movement is evidenced by sever truncation of the Sharawra, Qusaiba, Uqlah formations and Hawban Member of the Sarah Formation. In the northern part of the Qusayba depression, the Tawil Formation rests unconformably on the Sarah Formation.

The influence of the Acadian and glaciation events were used by Laboun to subdivide the succession into preAcadian (Qusaiba and Sharawra formations), synAcadian (Tawil Formation), and post-Acadian (Jauf Formation) (Figure 4).

\section{Pre-Acadian Stratigraphy:}

The following is a brief review of pre-Acadian lithostratigraphic units:

\section{Qusaiba Formation:}

Lithology: marine shale and minor shallow marine siltstone.

Age: Early Silurian

Underlying contact: disconformable with underlying Sarah Formation or has a sharp contact with the marine flooding surface with Uqlah Formation.

Sharawra Formation:

Lithology: shallow marine shale and deltaic sandstone siltstone and minor shale.

Age: Early Silurian

Underlying contact: disconformable with the underlying Qusaiba Formation.

Overlying contact: Unconformable with overlying Tawil Formation.

Tawil Formation:

Lithology: braided fluvial and shallow marine sandstone siltstone.

Age: Early Devonian

Underlying contact: unconformable with various older units; Sharawra, Qusaiba, and Sarah formations.

The Tawil Formation was divided by Janjou and others ${ }^{1}$ into four members. The members, from base to top, are; the Samra, Ghuwar, Tufayhah, and Juraniyat members.

\section{Structure of Tabuk and Widyan Basins:}

Tabuk basin is bounded to the west by the Red Sea escarpment and to the east by the northerly-plunging. The Paleozoic rocks form part of a large homocline structure trending north-northeast with a dip of about one degree. The basin is interrupted by a system of primary fractures oriented parallel to the axis of the Red Sea and by secondary fractures that strike northeast and north-south. Fayha graben and Tabuk graben are the main structural elements in the Tabuk basin ${ }^{1,2,4}$.

Paleozoic rocks in the Widyan basin to the east of the Hail Arch form a homocline structure that strikes N50W and dipping about 1-2 degrees to the northeast in the Baq'a quadrangle 6 . It strikes also $\mathrm{N} 35 \mathrm{~W}$ in Jabal Habashi and Buraydah quadrangles and dipping about 1 degree to the northeast ${ }^{7,8}$.

\section{Sharawra Formation:}

\section{Tabuk Basin:}

The Silurian succession exposed in the Tabuk basin is represented by Uqlah, Qusaiba, Sharawra, and the lower part? of the Tawil formations. This succession in the Tabuk and Qalibah quadrangles were studied and mapped by Janjou and others ${ }^{1,2}$.

Measured sections of the Sharawra Formation by Janjou and others ${ }^{1,2}$ are the following; at its reference section in Tabuk quadrangle, between Jabal Mukayhil and Tal Az Zufayyir (base lat. $281447 \mathrm{~N}$, long $371555 \mathrm{E}$, top lat. $282442 \mathrm{~N}$, long. $371642 \mathrm{E}$ ) and at its type section at Al Qalibah quadrangle, Ad Dahkiyah area (base lat. 28 $0218 \mathrm{~N}$, long. $375926 \mathrm{E}$, top lat. $281151 \mathrm{~N}$, long. 38 00 E. Vaslet and others ${ }^{6}$ measured a section at Baq'a quadrangle near Khashm Tayyarat (lat.27 $4435 \mathrm{~N}$, long. $424111 \mathrm{E})$. The present author measured the Sharawra Formation at Qusayba escarpment in the Buraydah quadrangle. These measured sections were used in this study (Figure 5).

The Sharawra Formation rests disconformably on the Qusaiba Formation. The upper contact with overlying Tawil Formation is marked by an erosion surface. The formation was subdivided by Janjou and others ${ }^{1}$ into four members. The members from base to top are: the Jarish, Khanafriyah, Nayyal, and Zubliyat members. The age of the Sharawra Formation was considered to be Llandoverian to Wenlockian (Early to Late Silurian) ${ }^{1}$.

\section{Sharawra Thickness Changes:}

The Sharawra Formation, in the Tabuk and Widyan Basins is disconformably overlain by the Tawil Formation. It is mainly composed of micaceous siltstone, claystone, and fine-grained sandstone.

The Sharawra Formation in Tabuk quadrangle shows a pronounced reduction in thickness eastward (Figure 5), as described in the following:

A-Tabuk basin:

The Sharawra Formation is 510 meters thick in its reference section between Tal Az Zufayyir and Jibal Al Midafi (base at lat. $282800 \mathrm{~N}$, long. $371642 \mathrm{E}$, top at lat. $285118 \mathrm{~N}$, long. $370612 \mathrm{E})$ in the Tabuk quadrangle. It is 422 meters thick in the Zubliyat area (base at lat $283118 \mathrm{~N}$., long 375618 E.) in the Qalibah quadrangle (Figure 5). 


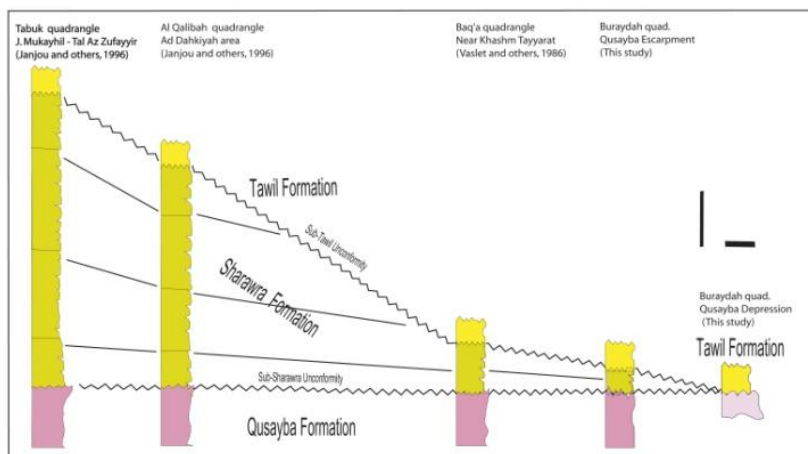

Fig. 5: Stratigraphic cross section of the Sharawra Formation from Tabuk area to Qusayba depression showing the influence of the subTawil unconformity in western and central Arabia. Top of the Qusaiba shale is used as a datum for the section.

\section{B- Nafud basin:}

Eastward, the Sharawra Formation in the An Nafud, and Jubbah quadrangles is covered by eolian sands and it is missing on the Hail quadrangle (Hail arch) (Figure 2).

C- Widyan Basin:

Baq'a-Buraydah Quadrangle:

The Sharawra Formation is exposed in the Baq'a and Buraydah quadrangles to the east of the Hail arch. The Sharawra Formation is 89 meters thick near Khashm Tayyarat at lat. $274435 \mathrm{~N}$, long. $424111 \mathrm{E}$, in the Baq'a quadrangle and 42 meters thick at Qusayba escarpment at lat. $265108 \mathrm{~N}$, long. $433448 \mathrm{E}$ in the Buraydah quadrangle (Figure 5).

Baq'a-Qusaiba Paleo-high:

The Sharawra Formation shows a pronounced thinning in the Baq'a-Qusayba area. It is entirely missing in the northern part of the Qusayba depression where the Early Devonian Tawil Formation rests unconformably on the Late Ordovician Sarah Formation (Figure 6).

At the present time the Hail arch separates the well exposed Silurian successions in the Tabuk basin, to the west, from the reduced of King Saud University Widyan basin, to the east. So it is considered that the Baq'a-Qusayba area is a Late Ordovician paleo-high (Figure 7).

On the Hail arch the Saq Formation is non-conformably overlies Precambrian Basement. The Saq was unconformably overlain by discontinuous paleo-valley deposits of the glacial Zarqa/Sarah Formations.

\section{Results and Conclusions:}

1- The Sharawra Formation shows a pronounced reduction in thickness eastward from Tabuk to Qusayba. 2- The Sharawra, Qusaiba, Uqlah formations and the Hawban Member of the Sarah Formation are missing in the northern part of the Qusayba depression.

3- The Devonian Tawil Formation rests unconformably on the Late Ordovician Sarah Formation at the Qusayba depression.

4- This truncation is probably caused by the Acadian uplift phase of the Caledonian time-equivalent movements.

5- These movements took place during Late SilurianEarly Devonian and successively eroded the Sharawra Formation and older units.

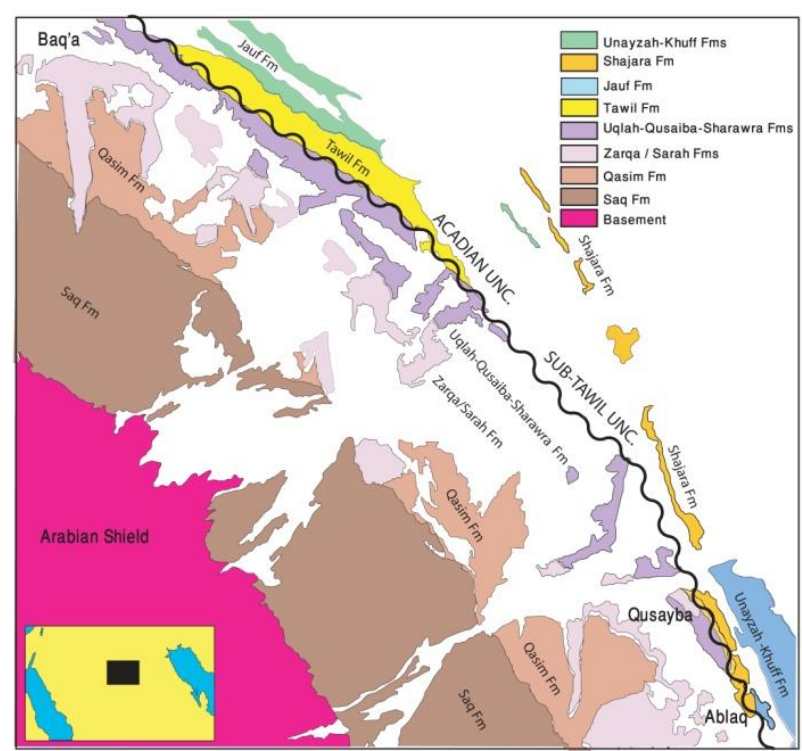

Fig. 6: Detailed geologic map from Baq'a area to Qusayba depression shows the influence of the Acadian tectonic movements (sub- Tawil unconformity) prior to the deposition of the Early Devonian Tawil Formation.

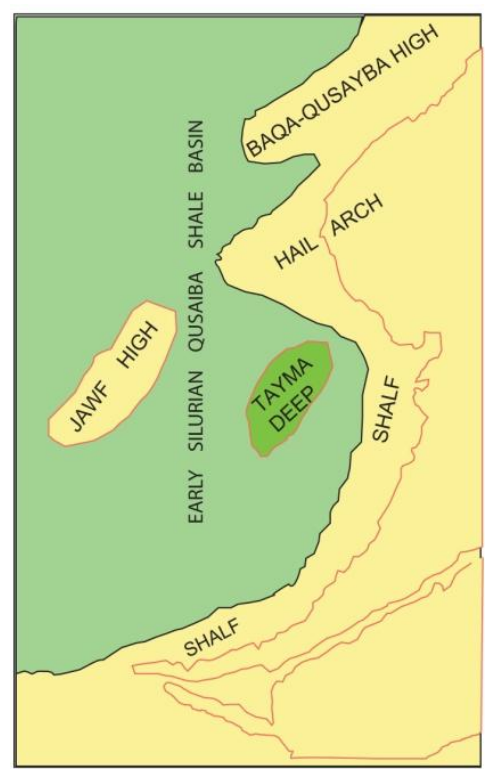

Fig. 7: Generalized distribution of the pre-Silurian, Late Ordovician paleo-highs. Note the Jawf, Hail, and Baq'a-Qusaiba highs.

6- The Early Devonian Tawil Formation rests unconformably on the Late Ordovician Sarah Formation in the Qusayba depression.

\section{ACKNOWLEDGMENTS}

The author is grateful to Nasir Al-Arifi of King Saud University, and Mansour Al-Ruwaili and Abdulaziz AlDuaiji of Saudi Aramco for helpful discussions and valuable comments. Thanks are due to Fahad, Abdulrahman, and Salih of the Al-Radi Family of Qusayba for their kind hospitality and help during the field work carried out by the author in the Qusayba area.

\section{References}

1) Janjou, D., Halawani, M.A., Al-Muallem, M.S., Brosse, J_M., Becq-Giraudon, J. F., Dagain, J., Genna A., Razin, P., Roobol, M.J., Shorbaji, H., and Wyns, R., 1996a: Geologic map of the Tabuk quad- 
rangle, sheet 28B, Kingdom of Saudi Arabia (with text): Saudi Arabian Deputy Ministry for Mineral Resources, Jiddah, Geoscience Map GM-137.

2) Janjou, D., M. A. Halawani, M. S. Al-Muallem, C. Robelin, J-M. Brosse, S. Courbouleix, J. Dagain, A. Genna, P. Razin, M. J. Roobol, H. Shorbaji, and R. Wyns, 1996b: Geologic map of the Al Qalibah quadrangle, sheet 28C, Kingdome of Saudi Arabia (with text): Saudi Arabian Deputy Ministry for Mineral Resources, Jiddah, Geoscience Map GM135.

3) Vaslet D., Janjou, D., Robelin, C., Al-Muallem, M. S., Halawani, M.A., Brosse, J-M., Berthiaux, A., Breton, J-P., Courbouleix, S., Roobol, M.J., and Dagain, J., 1994: Geologic map of the Tayma quadrangle, sheet 27C, Kingdome of Saudi Arabia (with text): Saudi Arabian Deputy Ministry for Mineral Resources, Jiddah, Geoscience Map GM134.

4) Janjou, D., M. Halawani, M. John Roobol, A. Memesh, Philippe Razin, H. Shorbaji, and J. Roger, 1998: Geologic map of the Jabal Misma quadrangle, sheet 27 D, Kingdome of Saudi Arabia (with text): Saudi Arabian Deputy Ministry for Mineral Resources, Jiddah, Geoscience Map GM-138.

5) Bartlett E., Vaslet, D., Berthiaux, A., Le Stat, P., and Fourniguet, J., 1986: Geologic map of the Hail quadrangle, sheet 27E, Kingdome of Saudi Arabia (with text): Saudi Arabian Deputy Ministry for Mineral Resources, Jiddah, Geoscience Map GM$115 \mathrm{C}$.

6) Vaslet D., Kellogg, K.S., Berthiaux, A., Le Start, P., and Vicent, P.L. 1987: Geologic map of the Baq'a quadrangle, sheet 27 F, Kingdome of Saudi Arabia (with text): Saudi Arabian Deputy Ministry for Mineral Resources, Jiddah, Geoscience Map GM$116 \mathrm{C}$.

7) Manivit, J., Vaslet D., Berthiaux, A., Le Start, P., and Fourniguet, J., 1987: Geologic map of the Buraydah quadrangle, sheet $26 \mathrm{G}$, Kingdome of Saudi Arabia (with text): Saudi Arabian Deputy Ministry for Mineral Resources, Jiddah, Geoscience Map GM-114 C.

8) Williams, P.L., Vaslet D., Johnson, P.R., Berthiaux, A., Le Start, P., and Fourniguet, J., 1987: Geologic map of the Jabal Habashi quadrangle, sheet 26F, Kingdome of Saudi Arabia (with text): Saudi Arabian Deputy Ministry for Mineral Resources, Jiddah, Geoscience Map GM-98C.

9) Powers, R. W., L. F. Ramirez, C. D. Redmond, and E. L. Elberg, Jr., 1966: Geology of the Arabian Peninsula - Sedimentary Geology of Saudi Arabia: U. S. G. Survey Professional Paper, 560-D, Washington.

10) Burchfiel H. L. and J. W. Hoover, 1935 (Aramco unpublished report, in Laboun, 1993: Lexicon of the Paleozoic and Lower Mesozoic of Saudi Arabia).
11) Pocock, R. W. and R. P. Kopp, 1949 (Aramco unpublished report, in Laboun, 1993: Lexicon of the Paleozoic and Lower Mesozoic of Saudi Arabia).

12) Bramkamp, R.A., C. W. Brown, S. J. Roach, and E. Clements (in Roach, 1951: Aramco unpublished report) (in Laboun, 1993, Lexicon of the Paleozoic and Lower Mesozoic of Saudi Arabia).

13) Thralls, W. H. and R. C. Hasson, 1956: Geology and Oil Resources of Eastern Saudi Arabia, International Geological Congress, 20 ${ }^{\text {th }}$, Mexico, Symposum Sobre Yacimentos, de Petroleo y gas, V. 2, p. 9-32.

14) Thralls, W. H. and R. C. Hasson, 1957: Saudi Arabia's Oil, two part, Oil and Gas Journal, part one; July 15, part two; July 22, 1957.

15) Steineke, M., Bramkamp, R.A., and Sanders, N.J., 1958: Stratigraphic relations of Arabian Jurassic oil: in L.G. Weeks, ed. Habitat of Oil, the American Association of Petroleum Geologist, pp. 1294-1329, Tulsa, Oklahoma, USA.

16) Powers, R.W., 1968, Lexique stratigraphique international: Saudi Arabia, V. III, Asie, fasc 10b 1 Centre National de la Recherche Scientifique, Paris, $177 \mathrm{p}$.

17) Rickards R. B. and T. N. Koren, 1974: Virgellar mesworks and secular spinosity in Llandovery graptoloids; Geological Magazine V. 3, pp. 193-272.

18) El-Khayal, A.A., 1985: Some Silurian (Llandoverian) monograptids from Saudi Arabia, Scripta Geolologica, V. 80, pp. 15-22.

19) El-Khayal, A.A., 1987: Silurian graptolites from the Qusayba shale (Llandovery) of central Saudi Arabia. Bulletin of the Geological Society of Denmark, V. 35, pp. 125-133.

20) El-Khayal, A.A., and Romano, M., 1988: A revision of the upper part of the Saq Formation and Hanadir Shale (Lower Ordovician) of Saudi Arabia, Geological Magazine, pp. 161-174.

21) McClure, H. A., 1988: The Ordovician Silurian boundary in Saudi Arabia; Bulletin, Museum (Natural History, Geology Series), V. 43, pp. 154163.

22) Laboun, A.A., 1982: The subsurface stratigraphy of the pre-Khuff formations in central and northwestern Arabia (Ph.D. thesis): Jiddah, King Abdulaziz University, pp. 102.

23) Laboun, A.A., 1986: Stratigraphy and hydrocarbon potential of the Paleozoic succession of both the Widyan and Tabuk basins, Arabia: in Halbouty, M., Future Petroleum Provinces of the World, American Association of Petroleum Geologists Memoir no. 50, p 373-394.

24) Laboun, A.A., 1987: Unayzah Formation: a new Permo-Carboniferous unit in Arabia: The American Association of Petroleum Geologists Bulletin, V. 71, no. 1, p. 29-38.

25) Laboun, A.A., 1988: The distribution of the Carboniferous-Permian siliciclastics in the Greater Arabian Basin, Geological Society of America Bulletin, V. 100, No. 3, pp. 362-373. 
26) Laboun, A.A., 1990: The Paleozoic succession and influence of the Hercynian equivalent movements in the Greater Arabian Basin, Journal King Abdulaziz University: Faculty of Earth Sciences, V. 3, special issue: $1^{\text {st }}$ Saudi Symposium on Earth Sciences, Jiddah, p 201-215.

27) Laboun, A.A., 1992a: Generalized chronostratigraphic section of the Paleozoic and Lower Mesozoic succession of the Middle East (the Greater Arabian Basin), King Abdulaziz city for Science and Technology, Riyadh.

28) Laboun, A.A., 1992b: The evolution of the stratigraphic nomenclature of the Paleozoic and Lower Mesozoic of Saudi Arabia, $1^{\text {st }}$ meeting of the Saudi Society for Earth Sciences, October 27-29, Riyadh.

29) Laboun, A.A., 1993: Lexicon of the Paleozoic and Lower Mesozoic of Saudi Arabia (Part-1: Lithostratigraphic units, Nomenclature review), Ibn Laboun Publishers, Box 63280 Riyadh 11516.

30) Laboun, A.A., 2000: Lithostratigraphy and oil and gas fields of Saudi Arabia, $4^{\text {th }}$ edition, Saudi Society for Earth Sciences, King Saud University, Faculty of Science, Geology Section, Riyadh.

31) Laboun, A.A., 2003: The Qusayba Depression: A Window on the Influence of the Caledonian and Hercynian Orogenies in Central Arabia, $84^{\text {th }}$ Arab Conference on Mineral Resources, Sana'a, Republic of Yemen, 13-16 October, p. 220-230.

32) Vaslet, D., 1987a: Geologie du Paleozoique; Permien Superieur, Tias, Jurassique; lithostratigrapie, in Y. M. Le Nindre, J. Manivit, and D. Vaslet, Historie geologique de la bordure occidentale de la plate-forme Arabe du Paleozoique inferieur au Jurassique Superieur: D. Sc. Thesis, University of Paris VI, Paris, France, V. 1, 413 p.

33) Vaslet, D., 1987b: Early Paleozoic glacial deposits in Saudi Arabia, a lithostratigraphic revision: Saudi Arabian Deputy Ministry for Mineral Resources Technical Record BRGM-TR-07-1, 24 p.

34) Vaslet, D., 1987c: The Paleozoic (pre-Late Permian) of central Arabia and correlations with neighboring regions; Saudi Arabian Directorate General of Mineral Resources Technical Record BRGM-TR07-2, $167 \mathrm{p}$.

35) Vaslet, D., 1989: Late Ordovician glacial deposits in Saudi Arabia, a lithostratigraphic revision of the early Paleozoic succession: Saudi Arabian Directorate General of Mineral Resources Professional Papers 2, p. 13-44.Technical Record BRGM-TR-07-1, $24 \mathrm{p}$.

36) Mahmoud, M.D., Vaslet, D., and Husseini, M.I.,
1992: The Lower Silurian Qalibah Formation of Saudi Arabia an important hydrocarbon source rock: The American Association of Petroleum Geologists Bulletin, V. 76, No. 10, pp. 1491-1506.

37) Roach, S. J., 1951 (Aramco unpublished report, in Laboun, 1993: Lexicon of the Paleozoic and Lower Mesozoic of Saudi Arabia).

38) Helal, A. H., 1964: On the Occurrence of Lower Paleozoic Rock in the Tabuk Area, Saudi Arabia, Neues Jahrbuch fur Geologie und Palaontologie Monatshefte, V. 7, pp. 391-414, Stuttgart.

39) Layne, Jr. N. M., and Reese, 1960: (Aramco unpublished report, in Laboun, 1993: Lexicon of the Paleozoic and Lower Mesozoic of Saudi Arabia).

40) Bramkamp, R.A., G. F. Brown, D. A. Holm and N. M. Layne Jr., 1963a: Geologic Map of the Wadi AsSirhan quadrangle, Saudi Arabia: U. S. Geological Survey Miscellaneous Geological Investigations Map-I-200A.

41) Bramkamp, R.A., Ramirez, L.F., Brown, G.F., and Pocock, A.E., 1963b: Geologic Map of the Wadi Ar Rimah quadrangle, Saudi Arabia: U. S. Geological Survey Miscellaneous Geological Investigations Map-I-206A.

42) Brown, G. F., R. O. Jackson, R. G. Bougue, and E. L. Elberg, Jr., 1963: Geologic Map of the Northwestern Hejaz quadrangle, Saudi Arabia: U. S. Geological Survey Miscellaneous Geological Investigations Map-I-204 A.

43) McClure, H. A., 1987: Early Paleozoic Glaciationin Arabia, Palaeogeography, Paleoclimatology, Palaeoecology, V. 25, p. 315-327.

44) Clark-Lowes, D. D., 1980: Sedimentology and mineralization potential of Saq and Tabuk formations, Imperial college of Science and Technology, London, Open-File Report CRC/IC 7, $88 \mathrm{p}$.

45) Lozej, G. P. 1983: Geological and Geochemical Reconnaissance Exploration of the Cover Rocks in Northwestern Hijaz - Initial Results and Recommendations, Saudi Arabia, Deputy Ministry for Mineral Resources, Open-File Report RF-OF-032, pp. 135.

46) Le Strat, P., D. Vaslet, A. Berthiaux, and J. Manivit, 1985: Sedimentary Evolution of the Cambrian to Late Jurassic in the Qasim and Hail Regions, Saudi Arabian Deputy Ministry for Mineral Resource, Jeddah, Open-File Report BRGM-OF-04-42, pp. 52.

47) Dunnington, H. V., R. Wetzel, D. M. Morton, and R. C. Van Bellen, 1959: Lexique Stratigraphique International, Iraq; Centre National de la Recherche Scientifique, Paris, V. III, Asie, fasc. 10a, pp.177. 